\title{
WACANA PENDIDIKAN ISLAM MULTIKULTURAL UNTUK KEHARMONISAN HIDUP BERBANGSA
}

\author{
Dalmeri \\ Universitas Indraprasta \\ Pendidikan Guru Republik Indonesia-Jakarta \\ Email: dalmeri300@gmail.com
}

\begin{abstract}
Indonesia's diversity of ethnic, culture, tradition, and religion have aroused the dynamics of cultural diversity and positive civilization. If it is not managed wisely and comprehensively, it will cause conflict and disintegration. Multicultural education in Indonesia should not only become an academic discourse, but it also needs to be implemented in the concrete sphere in the educational realm. A conceptual frame for its implementation is neded, that is why, the problems caused by the effects of the diversity and religious bias do not become a heavy burden for the country. As for the students, this paper explains multicultural education in Islamic education and process to cultivate values of beliefs and importance of unique recognition for every ethnic, culture, and other social groups.
\end{abstract}

Keywords: Islamic education, Multicultural, Tolerance, Egalitarian, Humanism, Inclusive.

\begin{abstract}
ABSTRAK
Indonesia memiliki keragaman etnis, budaya, tradisi, kelompok sosial, agama, dan sebagainya, di satu sisi, telah menimbulkan dinamika keragaman budaya dan peradaban positif. Di sisi lain hal ini akan memicu konflik dan disintegrasi, jika tidak dikelola secara bijaksana dan komprehensif. Pendidikan multikultural di Indonesia sebagai solusi dan tidak hanya menjadi wacana akademis serta perlu dilaksanakan dalam lingkup kehidupan sosial, di antaranya adalah di bidang pendidikan. Penelitian ini berupaya menganalisis kerangka konseptual dalam pelaksanaan pendidikan multikultural sehingga masalah yang muncul sebagai efek dari keragaman tidak menjadi beban berat bangsa ini. Tulisan ini berupaya untuk menguraikan tentang pendidikan multikultural yang dapat diterapkan pada reformasi di bidang pendidikan Islam serta proses pendidikan yang menanamkan kepada peserta didik akan pentingnya nilai-nilai dan keyakinan yang diyakini keunikannya pada setiap etnis, budaya, dan kelompok sosial lainnya.
\end{abstract}

Kata Kunci: Pendidikan Islam, Multikultural, Toleransi, Egaliter, Humanis, Inklusif. 


\section{PENGANTAR}

Pengalaman hidup berbangsa dan bernegara yang dijalani oleh Umat Islam Indonesia telah menunjukkan bahwa mereka kaya dengan berbagai pengalaman dan pelajaran pahit dari berbagai konflik dan kerusuhan sosial yang terjadi pada beberapa bagian wilayah Negara Kesatuan Republik Indonesia ini. Semua ini telah menyadarkan mayoritas umat Islam bahwa mereka berperan sebagai unsur penting pada suatu bangsa yang multi etnik, multi kultural, multi budaya, bahkan multi agama.

Kenyataan ini menjadi kebanggaan dalam kehidupan kebangsaan yang bersifat multi etnik dan multi budaya seperti Indonesia yang dianggap sebagai salah satu negara multikultural yang paling mejemuk di dunia. Keragaman tersebut tidak jarang menjadi sumber konflik sektarian, kekerasan komunal, yang bermuara dari multikultural dan terbukti tidak menjanjikan bagi sebuah kehidupan yang nyaman, sejahtera, adil, dan demokratis. Sekalipun hal tersebut tidak terbukti menjadi suatu kenyataan pada pesta demokrasi Pemilihan Umum Legislatif maupun Pemilihan Presiden yang baru selesai pada bulan Juli 2014 ini.

Semua ini menjadi bahan analisis bagi beberapa peneliti di Indonesia maupun di luar negeri yang menyatakan bahwa negeri yang mayoritas penduduknya beragama Islam mampu melaksanakan demokratisasi dengan baik dan pantas menjadi contoh bagi negeri-negeri Muslim lainnya. Dalam sepuluh tahun terakhir ini, perhatian peneliti terhadap tema tersebut semakin meningkat. Ada berbagai cara peneliti dalam memahami keragaman di Indonesia tidak hanya mendeskripsikan identitas masing-masing kelompok, melainkan penggambaran pola interaksi masing-masing kelompok; apakah berpola konflik, integratif, akomodatif, maupun kompetitif.

Salah satu identitas kelompok yang banyak menarik perhatian banyak peneliti adalah keragaman agama sebagai salah satu faktor krusial dalam interaksi sosial maupun politik antara masing-masing kelom- pok. Bagaimana pola pendidikan Islam multikultural untuk keharmonisan hidup berbangsa? Untuk mengurai persoalan ini diperlukan sebuah wawasan kebangsaan yang menjunjung tinggi nilai-nilai egalitarianisme, humanisme, dan inklusifisme yang didasarkan kepada nilai-nilai yang diajarkan dalam pendidikan Islam

Sebagian besar masyarakat menyadari bahwa kekerasan sudah sedemikian merajalela pada semua aspek kehidupan. Pada bidang politik, manipulasi dalam pemilihan umum dan segala bentuk kecurangan akan memicu berbagai bentuk kekerasan; bidang ekonomi, korupsi, dan perampasan harta secara ilegal merupakan bentuk kekerasan; bidang hukum, pelanggaran aturan adalah bentuk kekerasan; bidang budaya, eksploitasi nilai-nilai negatif yang merusak peradaban merupakan bentuk kekerasan.

Media massa juga dapat menampilkan tayangan kekerasan. Bahkan media massa yang seringkali mempercepat pembelajaran untuk terjadinya berbagai tindakan kekerasan. Demikian pula halnya dengan bidang pendidikan, bentuk-bentuk hukuman atau sanksi yang kelewat batas, penyalahgunaan wewenang, pemaksaan dan tekanan atau menyalahi kode etik, dan norma kepatutan, juga disebut sebagai kekerasan.

Jika diamati dalam kehidupan beragama, setiap umat Islam yang berada di lingkungan masyarakat tertentu akan didapati dua atau lebih golongan atau kelompok masyarakat, seperti ada golongan Islam meliputi NU, Muhammadiyah, al-Irsyad, al-Washliyah, Ahmadiyah, Syi'ah-Sunni, dan sebagainya. Sementara itu, dalam Kristen mencakup Katolik, Evangelical, Ekuiminical, Dominican, Protestan, dan lain-lain. Selain itu, ada juga Hindu, Budha, Kong $\mathrm{Hu} \mathrm{Cu}$; serta ada pula pengelompokan lain, seperti masyarakat pribumi, non pribumi, yang dipertajam oleh perbedaan tingkat kehidupan masingmasing golongan atau kelompok, yang sedang menimbulkan permasalahan sosial sebagaimana yang dialami oleh bangsa Indonesia belakangan ini. 
Perbedaan suku, agama, ras, tradisi, budaya, antar golongan, antar dan intern agama, dan lain-lain itulah yang selalu didakwa sebagai perbedaan yang akan sarat dengan muatan konflik serta dapat mengancam perpecahan. Pada hal keberadaan seseorang yang terlahir dalam perbedaan-perbedaan tertentu, sebenarnya bukanlah pilihannya, melainkan sebagai sebuah keniscayaan yang melekat pada kenyataan yang menyatu pada kemanusiaannya. Tulisan ini berupaya untuk menganalisis tentang wacana pendidikan Islam yang berwawasan multikultural untuk keharmonisan dalam hidup berbangsa seperti Indonesia, mengingat Umat Islam berperan penting dalam menjaga keutuhan bangsa yang sangat menjemuk ini.

\section{PEMBAHASAN \\ Pendidikan Islam Berwawasan Multikultural}

Pendidikan Islam multikultural merupakan wahana untuk mengembangkan wawasan, mengkonstruksi pengetahuan, membina sikap toleran dan memberikan keterampilan kepada siswa untuk hidup "bersama" dengan siswa lain yang berbeda budaya maupun agama.

Gagasan dasar dari pendidikan Islam multikultural adalah bagaimana seluruh siswa laki-laki, perempuan, yang sehat dan cacat, miskin, kaya, terdiri atas berbagai kelompok ras, agama, gender, dan etnik yang beragam, ataupun berbicara dalam ragam bahasa seluruhnya memiliki kesempatan yang sama untuk belajar di sekolah, maupun institusi pendidikan tinggi lainnya.

Pendidikan Islam multikultural sebagai sebuah gagasan pendidikan yang ingin memberikan kesetaraan dan pengakuan akan ragam budaya yang memiliki sejarah panjang. Praktek pendidikan multikultural di berbagai negara, baik di Barat maupun di Timur telah menghasilkan suatu kesepakatan bersama bahwa salah satu pilar pendidikan adalah "living together" yakni memberikan latihan dan keterampilan kepada para siswa maupun mahasiswa akan pentingnya pengakuan dan penghargaan kepada orang yang memiliki ragam bahasa, budaya, etnis maupun agama (Tillman, 2004: xii).

Menghadapi berbagai persoalan ini maka yang diperlukan sebagai landasan yang kokoh bagi pembangunan sistem demokrasi di dalam masyarakat Indonesia yang sangat majemuk ini sebagai aplikasi pilihan perspektif pendidikan yang merupakan sintesis dari aplikasi perspektif pendidikan asimilasionis dan pluralis. Karena itu, dari perspektif pendidikan hal ini akan berperan dalam pendidikan multikultural sebagai instrumen bagi pengembangan eklektisisme dan sintesis terhadap beragam kebudayaan sub-nasional pada tingkat individual dan masyarakat. Sekaligus promosi bagi terbentuknya suatu "melting pot" dari beragam kebudayaan dan masyarakat.

Dengan demikian, pilihan perspektif pendidikan "sintesis multikultural" sesungguhnya memiliki asumsi yang paling dasar pada hakekat dan tujuan pendidikan multikultural, yang dapat diidentifikasikan melalui tiga tujuan, yaitu (1) tujuan attitudinal; (2) tujuan kognitif: dan (3) tujuan instruksional (Ekstrand, 1997:349). Pada tingkat attitudinal, pendidikan multikultural memiliki fungsi untuk menyemaikan dan mengembangkan sensitivitas kultural, toleransi budaya, penghormatan terhadap identitas tradisi, pengembangan sikap budaya responsif, dan keahlian untuk melakukan penolakan dan resolusi konflik.

Pada tingkat kognitif, pendidikan multikultural memiliki tujuan bagi pencapaian kemampuan akademik, pengembangan pengetahuan tentang kemajemukan kebudayaan, kompetensi untuk melakukan analisis dan interpretasi perilaku kultural, dan kemampuan untuk membangun kesadaran kritis tentang kebudayaan sendiri. Pada tingkat instruksional, pendidikan multikultural memiliki tujuan untuk mengembangkan kemampuan untuk melakukan koreksi atas distorsi-distorsi, stereotype-stereotype, maupun kesalahan informasi tentang kelompok-kelompok etnik dan kultural yang dimuat di dalam berbagai buku dan media pembelajaran, menyediakan strategi-stra- 
tegi untuk melakukan hidup di dalam pergaulan multikultural, mengembangkan berbagai bentuk keterampilan komunikasi inter-personal, menyediakan teknik-teknik untuk melakukan evaluasi, dan membantu menyediakan klarifikasi dan penjelasan-penjelasan tentang dinamika perkembangan kebudayaan yang melingkupi umat beragama di Indonesia, terutama Umat Islam.

Konsep Pendidikan Islam Multikultural

Kajian terhadap konsep multikultural memang perlu dikaitkan dengan asal usul konsep multikultural agar diketahui latar belakang sosiologis pengembangan konsep multikultural dan relevansinya dengan kondisi yang berkembang di Indonesia. Beberapa kajian terhadap multikultural, misalnya yang dilakukan oleh Melani Budianta (2004), Hilda Hernandez (2001), Will Kymlicka (2003), Donna M. Gollnick dan Philip C. Chinn (2002), H.A. R. Tilaar (2004), dan Alo Liweri (2005), yang menyatakan bahwa negara-negara Barat seperti Amerika, Kanada, Australia, Jerman, dan Inggris, sering disebut sebagai asal mula konsep multikultural. Di negara-negara tersebut, konsep multikultural tidak lagi sebagai wacana akademik, melainkan telah menjadi bagian strategis kebijakan publik seperti yang berbentuk affirmative action, yaitu suatu program pemberdayaan terhadap kelompok tertentu yang dikategorikan sebagai minoritas (Horton and L. Hunt, 1992). Di negara-negara tersebut, multikultural juga dijadikan sebagai kerangka acuan dalam merancang suatu program pendidikan yang mengakomodasi keragaman masyarakat.

Ada dua pertimbangan utama yang melatarbelakangi penggunaan multikultural sebagai acuan dalam merancang kebijakan publik di negara-negera tersebut.

Pertama, keragaman masyarakat. Negara-negara yang telah disebutkan di atas, dihuni oleh penduduk yang memiliki latar belakang sosial-budaya yang beragam. Kedua, terjadinya segregasi sebagai kelanjutan dari keragaman. Dalam konteks ini, Amerika dapat dijadikan contoh. Sebelum mengalami perubahan sebagai masyarakat yang didasarkan pada prinsip multikultural, Parsudi Suparlan mengemukakan bahwa Amerika merupakan masyarakat rasis yang menghasilkan hierarki sosial dengan berbagai bentuk diskriminasi atas dasar ras dan asal suku bangsa (Suparlan, 2003: 24). Dari pelbagai ras dan sukubangsa di Amerika, golongan WASP (White Anglo Saxon Protestant), menempati posisi mayoritas dan dominan. Sedangkan di pihak lain, mereka yang berkulit hitam merupakan kelompok minoritas, dan seringkali mendapat perlakuan yang diskriminatif.

Salah satu sektor publik yang diberlakukan secara diskrimiatif adalah pendidikan. Di awal-awal perkembangan-nya, pendidikan di Amerika selalui diwarnai dengan praktik diskriminatif. H.A.R. Tilaar dalam bukunya Multikulturalisme: Tantangan Global Masa Depan dalam Transformasi Pendidikan Nasional (2004) memaparkan secara singkat praktik diskriminatif pada wilayah pendidikan di Amerika yang dikenal dengan pendidikan yang bersifat segregasi sebagai bentuk awal pendidikan di Amerika sebelum munculnya pendidikan multikultural (Tilaar, 2004: 18).

Sejalan dengan makna istilah segregasi, maka dalam pendidikan yang bersifat segregasi terjadi perbedaan pelayanan program pendidikan antara mereka yang berkulit putih dengan mereka yang berkulit hitam. Kelompok kulit putih memperoleh hak pelayanan pendidikan yang berkualitas. Sedangkan kelompok kulit hitam justur sebaliknya. Kebijakan ini tentu saja menimbulkan ketidakpuasan dan gerakan perlawanan. Salah seorang aktor perlawanan yang banyak disebut dalam pelbagai kajian multikulturalisme adalah Martin Luther King. Tokoh Protestan yang dikenal dengan pidatonya, I have a dream, merintis gerakan yang disebut civil rights movement. Tujuan utama gerakan ini adalah menghapus segala bentuk diskriminasi yang juga terjadi dalam lingkungan pendidikan di Amerika. Dalam bidang pendidikan, civil rights movement menurut H.A.R. Tilaar telah melahirkan suatu praksis pedagogi baru yang mem- 
berikan kesempatan serta penghargaan yang sama terhadap semua warga sipil tanpa membedakan asal usul serta agamanya. Praksis pendidikan ini disebut juga dengan pendidikan multikultural.

Keragaman masyarakat yang menjadi dasari bagi pengembangan pendidikan multikultural seperti pengalaman Amerika dan beberapa negara Barat lainnya, memiliki kemiripan dengan perkembangan di Indonesia sehingga multikultural memiliki relevansi dijadikan sebagai titik tolak dalam mengelola keragaman atau kemajemukan di Indonesia.Keragaman yang berkembang di Indonesia telah lama menjadi perhatian para ahli. Di antaranya adalah J.S. Furnivall yang menawarkan konstruks plural societies (masyarakat majemuk) sebagai ideal type masyarakat Indonesia (Nasikun, 1992). Furnivall nampaknya memiliki alasan rasional terhadap penggunaan konstruks tersebut. Hal yang menarik dari konstruks Furnivall bukan pada pengakuannya terhadap kenyataan keragaman di Indonesia yang juga dinyatakan oleh ahli lainnya.

Sementara itu, Parsudi Suparlan menyebutkan bahwa angka 500 sebagai jumlah suku bangsa yang mendiami Negara Kesatuan Republik Indonesia. Konsep plural societies yang ditawarkan Furnivall bukan hanya didasarkan pada fakta statistik tersebut, tetapi lebih pada pola interaksi yang berkembang antar kelompok-kelompok sosial di Indonesia.

Penelitian Furnivall menemukan bahwa kemajemukan masyarakat Indonesia tidak diimbangi dengan pembauran dan memperlihatkan segregasi antar masingmasing kelompok sosial. Perkembangan kemajemukan yang digambarkan oleh Furnivall jelas tidak menguntungkan bagi masa depan masyarakat di Indonesia karena berpotensi melahirkan konflik sosial secara terbuka. Kemungkinan munculnya konflik sosial dalam masyarakat majemuk semakin diperjelas dalam kajian Pierre L. van den Berghe yang mengemukakan enam karakteristik dasar masyarakat majemuk, yakni: (1) terjadinya segmentasi ke dalam bentuk-bentuk kelompok yang seringkali memiliki sub kebudayaan yang berbeda satu sama lain; (2) memiliki struktur sosial yang terbagi-bagi ke dalam lembaga-lembaga yang bersifat non-komplementer; (3) kurang mengembangkan konsensus di antara para anggotanya terhadap nilai-nilai yang bersifat dasar; (4) secara relatif seringkali mengalami konflik-konflik di antara kelompok yang satu dengan kelompok yang lain; (5) secara relatif integrasi sosial tumbuh di atas paksaan (coercion) dan saling ketergantungan di dalam bidang ekonomi; dan (6) adanya dominasi politik oleh suatu kelompok atas kelompokkelompok yang lain (Nasikun, 1992: 62).

Jadi dapat dikemukakan bahwa multikultural bisa berkoherensi dengan modal sosial. Salah satu cara untuk mengetahui adanya koherensi tersebut adalah dengan memahami pengertian modal sosial. Mengingat terbatasnya ruang pembahasan, tidak semua definisi dikemukakan tetapi hanya beberapa yang dianggap memberikan pemahaman terhadap konsep modal sosial.

Sementara itu, Francis Fukuyama mengartikan bahwa modal sosial, sebagai seperangkat nilai atau norma informal yang dimiliki bersama oleh anggota suatu kelompok yang memungkinkan kerja sama di antara mereka (Fukuyama, 1995: 19). Definisi berikutnya berasal dari Putnam, salah seorang ahli yang memopulerkan konsep modal sosial. Menurutnya, modal sosial menunjuk pada bagian-bagian dari organisasi sosial seperti kepercayaan, norma dan jaringan, yang dapat meningkatkan efisiensi masyarakat dengan memfasilitasi tindakan-tindakan yang terkoordinasi (Lawang, 2004: 34).

Denganadanyakepercayaan, masyarakat akan mudah merancang suatu jaringan sosial atas prinsip kesukarelaan (voluntary), kesamaan (equality), kebebasan (freedom) dan keadaban (civility). Unsur berikutnya adalah norma, yakni sekumpulan aturan yang harus dipatuhi oleh masyarakat yang terlibat dalam jaringan sosial (Hasbullah, 2006: 8).

Berdasarkan analisis di atas posisi pendidikan sebagai salah satu institusi 
yang dapat memanfaatkan sebagai tempat pelembagaan studi agama berbasis pendidikan multikultural. Dalam insititusi pendidikan, diharapkan bisa dihindari adanya silang sengkarut agama di ranah sosial, karena ketidakmampuan dalam mengelola relasi agama pada wilayah pribadi dengan dengan wilayah sosial agama.

Perlu disadari kembali, menurut kajian dan analisis filsafat dan psikologi, agama menempati posisi paling penting dalam kehidupan manusia. Bahkan agama menjadi bagian penting dalam cara manusia mengada, bisa dibuktikan dari objek yang paling banyak dicari oleh manusia sepanjang hayatnya. Sejarah primitif manusia selalu diwarnai oleh pencarian terhadap agama. Dari beberapa hasil kajian dalam ilmu-ilmu sosial, agama selalu disebut sebagai salah satu aspek yang paling banyak mewarnai historisitas manusia. Tentu saja, mengiringi kesederhanaan peradaban manusia, konstitusi agama manusia seperti dalam studi yang dilakukan oleh Emile Durkheim, juga bercorak elementer.

Proses pencarian manusia terhadap agama adalah kelanjutan belaka dari karakter manusia yang sejatinya merupakan makhluk religius. Dari sudut pandang kajian keislaman, agama pertama-tama diposisikan sebagai fitrah majbulah. Maksudnya, dalam diri manusia terdapat potensi beragama, sehingga manusia dalam pandangan Islam mudah menerima agama. Agama sebagai sesuatu yang diwahyukan, dalam Islam disebut dengan fitrah munazzalah. Tidak perlu dipersoalkan wujud eksoteris agama yang dipeluk manusia. Sebab apapun wujudnya, penemuan dan penerimaan manusia terhadap agama pasti berawal dari kenyataan "misteri yang menggentarkan," dan "misteri yang memesonakan." Semua agama yang dipeluk manusia, baik yang melalui proses budaya maupun wahyu, bisa dipastikan terobsesi dengan kedua hal tersebut.

Hal itulah yang membuat manusia memandang agama sebagai sesuatu yang demikian bermakna, tidak saja bagi dirinya sebagai makhluk pribadi, tetapi juga bagi kehidupan kolektifnya dengan komunitas manusia lainnya. Agama secara sosiologis menjadi identitas kelompok yang sulit dihilangkan. Ada kecenderungan yang sulit dihilangkan dalam kehidupan manusia secara berkelompok. Manusia selalu mengidentifikasi dirinya dengan agama kelompoknya. Kecenderungan lain setelah agama mengalami eksternalisasi dan objektivikasi sebagai realitas kelompok, pada masing-masing anggota kelompok selalu menjaga eksistensi kelompoknya terutama jika ada penetrasi dari kelompok lain. Oleh karena itu, muncul kecurigaan atau prasangka terhadap kelompok lain. Dan, tidak bisa dipungkiri, agama merupakan salah satu bagian dari prasangka. Prasangka itu, misalnya, tampak pada penilaian subjektif bahwa agama lain sebagai ancaman. Phobia terhadap keberadaan kelompok agama lain pun bersemai. Semua prasangka itu muncul dari pemahaman subjektif, tanpa perlu melakukan pemahaman secara fenomenologis.

Salah satu institusi sosial penting dan strategis guna menanamkan konstruks yang lebih bersimpati dan berempati terhadap keberadaan agama lain adalah pendidikan. Munculnya usaha-usaha konstruktif untuk semakin mendekatkan jarak sosial antar kelompok agama. Kegiatan dialog lintas agama sebagai salah usaha yang konstruktif tersebut, perkembangannya cukup menggembirakan belakangan ini. Meski demikian, tetap saja ada kritik terhadap usaha tersebut. Efek yang ditimbulkan dari kegiatan dialog lintas agama hanya terbatas pada kalangan tertentu, yaitu kalangan elitenya saja. Seringkali pula tema-tema yang didialogkan kurang sistematis. Karena itu, sudah saatnya institusi pendidikan dimanfaatkan sebagai tempat persemaian untuk menumbuhkan sikap egaliter terhadap keberadaan agama lain. Dalam institusi yang memang sudah teruji ini, perlu dikembangkan pembelajaran agama bercorak multikultural yang dimulai sejak anak dalam usia dini. Pembelajaran agama bercorak multikultural, bisa dipahami sebagai suatu proses penyadaran terhadap 
adanya keanekaragaman agama serta kesediaan memberlakukan setiap agama secara egaliter. Dalam pembelajaran agama bercorak multikultural, seluruh warga belajar diajak menghayati secara fenomenologis keragaman agama di luar agama yang dipeluknya. Dalam rangka itu, para warga belajar diberi penguatan agar bisa mentransformasikan pengalaman agamanya yang subjektif, ke pengalaman subjektivitas ganda.

Pada subjektivitas ganda, pengalaman masing-masing pribadi didialogkan untuk bersama-sama mencari titik temunya. Tentu saja, pembelajaran agama yang diharapkan bisa mendorong tumbuhnya pengalaman subjektivitas ganda, harus bertitik tumpu pada landasan teologi dan filsafat tentang kesetaraan agama. Jika pendidikan bisa digarap serius sebagai media untuk menumbuhkan sikap egaliter terhadap semua agama, maka keragaman agama bukan lagi sebagai ancaman.

Pada tataran praktis, studi agama berbasis multikultural perlu diterapkan dengan memanfaatkan metode living values. Metode living values merupakan elaborasi operasional dari prinsip pendidikan yang telah dirumuskan oleh UNESCO, lembaga PBB yang mengurusi persoalan pendidikan di dunia. UNESCO PBB merumuskan empat prinsip pendidikan, yakni: belajar untuk melakukan (how to do), belajar untuk mengetahui (how to know), belajar untuk hidup bersama (how to life together), dan belajar menjadi diri yang sejati (be coming, tobe). Persoalan yang muncul adalah bagaimana implementasi keempat prinsip ini dalam praksis pendidikan.

Pada tahun 1996 sekitar 20 pengajar dari seluruh dunia berkumpul di kantor pusat UNICEF di New York mendiskusikan cara mengajarkan nilai. Pertemuan tersebut berhasil merumuskan konsep pendidikan nilai yang dikenal Living Values: An Educational Program (LVEP), yang menekankan pada metode living values dalam mengajarkan nilai (Tillman, 2004). Pilihan terhadap metode living values karena studi agama multikulturalisme juga menekankan pada nilai yang dibutuhkan dalam kehidupan beragama. Metode living values dengan demikian juga berkelindan dengan modal sosial yang menekankan pada kepercayaan, jaringan, dan norma (Rahman, 2012: 6).

Pelaksanaan metode living values dalam pendidikan terdiri dari beberapa tahapan. Melalui tahapan-tahapan ini metode living values dapatmenyatukan antara pembentukan atmosfir nilai di lembaga pendidikan dengan nilai-nilai dalam kehidupan.

Dengan demikian, pendidikan multikultural secara sederhana dapat dirumuskan sebagai sistem nilai atau kebijakan yang menghargai keragaman dalam suatu masyarakat yang didasarkan kepada kesediaan untuk menerima dan menghargai keberadaan kelompok lain yang berbeda suku, etnik, jender, maupun agama (Anwar, 2006: 2). Secara normatif-teologis, Islam sebenarnya sejak awal telah mengajarkan nilainilai penghormatan dan penghargaan atas keragaman yang ada, apapun perbedaan yang muncul di bumi ini. Paling tidak ada tiga perspektif untuk melihat kaitan antara Islam dengan Pendidikan Multikultural.

\section{Perspektif Teologis}

Ada beberapa ayat Al-Qur'an yang secara jelas dan sangat apresiatif terhadap tumbuhnya nilai-nilai perbedaan, baik gender, bangsa maupun suku, seperti disebutkan dalam Al-Qur'an:

Artinya: Hai manusia, Sesungguhnya kami menciptakan kamu dari seorang laki-laki dan seorang perempuan dan menjadikan kamu berbangsa - bangsa dan bersuku-suku supaya kamu saling kenal-mengenal. Sesungguhnya orang yang paling mulia diantara kamu disisi Allah ialah orang yang paling taqwa diantara kamu. Sesungguhnya Allah Maha Mengetahui lagi Maha Mengenal (Q.S.: Al-Hujarat: 13).

Keharusan untuk saling menghormati dan menghargai di antara perbedaan bahasa dan warna kulit. Juga ditunjukkan pada firman Allah SWT. 
Artinya: Dan di antara tanda-tanda kekuasaanNya ialah menciptakan langit dan bumi dan berlain-lainan bahasamu dan warna kulitmu. Sesungguhnya pada yang demikan itu benarbenar terdapat tanda-tanda bagi orang-orang yang Mengetahui (Q.S.: Ar-Ruum: 22).

Kedua ayat Al-Qur'an yang pertama, Al-Hujarat: 12 dan Al-Ruum: 22 di atas, telah memberikan beberapa aksentuasi penting tentang pengakuan keberadaan "orang lain" menjadi bagian tak terpisahkan dari yang "lain". Perbedaan gender, bangsa, suku, bahasa, warna kulit, adalah semata-mata perbedaan artifisial yang sudah dikonstruki oleh Allah dalam rangka pemenuhan kebutuhan kelengkapan hidup dan kehidupan di dunia. Inilah yang kemudian disebut dengan Sunnatullah yang bisa menimpa siapa saja yang hidup di dunia.Jika demikian adanya, maka setiap perbedaan yang muncul-termasuk perbedaan tradisi atau budaya dan lain-lain-yang melekat pada setiap umat bukanlah perbedaan yang muncul secara tiba-tiba, tapi sudah dikonstruk sedemikian rupa oleh yang mengkonstruk, yaitu Allah SWT. Mengingat perbedaan tersebut merupakan Sunnatullah, maka siapa pun yang ada di kosmos ini harus dan wajib mengakui keberadaan "orang lain" sebagai bagian dari yang "lain" untuk bisa menghirup dan hidup di udara yang sama ini. Dengan demikian, siapa pun yang mengingkarinya, sudah barang tentu menyalahi, bahkan keluar dari Sunnatullahatau mungkin menantang kodrat-Nya.

Dengan demikian, landasan teologisnormatif di atas sebenarnya telah memberikan kejelasan justifikasi mengenai hubungan antar sesama yang telah melampaui batas-batas etnis, ras, kelompok, golongan, bahkan agama sekalipun. Untuk itu, bangunan wawasan kebangsaan yang menjunjung tinggi nilai-nilai egalitarian, pluralitas, multikultural, humanis, dan inklusif, tidaklah jauh dari semangat keislaman. Islam di bawa ke muka bumi justru untuk menciptakan nilai-nilai universal tersebut sebagaimana misi besarnya sebagai agama "cinta damai" dan "rahmat bagi semua makhluk" (rahmatan li al-'Alam³n).

\section{Perspektif Historis}

Jika ditilik ke belakang, sejarah panjang Nabi Muhammad SAW. telah menunjukkan betapa pentingnya menjunjung prinsipprinsip dasar nilai plural dan multikultural. Beliau sendiri telah hidup di tengahtengah komunitas yang sangat plural dan multikultural. Dia membangun kebersamaan di tengah keragaman atas dasar teologi "la ilaha illallah" di Mekah selama 13 tahun, kemudian hijrah ke Yatsrib, yang kemudian berganti nama menjadi Madinah. Masyarakatnya tidak hanya terdiri dari satu etnis, suku, bangsa, maupun agama; namun sangat beragam. Ada sejumlah suku dominan yang mendiami kota itu. Suku Aus, Khajraj, Qainuqa, Quraidlah, dan Bani Nadzir. Demikian pula penduduknya menganut beragam agama: Islam, Yahudi, dan sebagian kecil Kristen Najran.

Masyarakat Islam sendiri terdapat dua latar belakang, yaitu kaum migran atau pendatang yang disebut dengan sahabat Muhajirin (dari beberapa suku asal Mekah dan sekitarnya), dan penduduk lokal yang biasa disebut sahabat Anshar, yang didominasi oleh suku Aus dan Khajraj. Sedangkan kaum Yahudi lebih berasal dari suku Nadzir, Qainuqa, dan Quraidlah. Dari keberagaman inilah, kemudian Nabi membuat suatu kesepakatan yang mengikat antar ragam yang ada, demi membangun kebersamaan, saling hormat dan menghargai akan hak dan kewajiban masing-masing, sehingga terjalin komunitas yang tidak hanya stabil dan harmonis tapi juga bisa hidup saling berdampingan.

Kondisi masyarakat yang cukup plural dan multikultural tersebut, telah menginspirasi Nabi Muhammad SAW. untuk mendirikan apa yang kemudian dikenal dengan "Negara Madinah". Konsep Negara Madinah tertuang dalam Piagam Madinah", yang mengandung nilai-nilai universalitas: Keadilan, kebebasan, persamaan hak dan kewajiban, serta perlakuan sama di mata hukum.

Inilah yang kemudian dijadikan landasan oleh pesantren-pesantren di Indonesia pada 
umumnya. Dalam kaitan ini, ada beberapa tradisi yang telah lama ditunjukkan oleh dunia pesantren, di mana pesantren adalah lembaga pendidikan Islam tertua dalam perkembangan dinamika sejarah Indonesia. Berdasarkan hasil studi yang dilakukan oleh para pengamat, telah menunjukkan bahwa sejak awal perkembangannya (awal Abad XVI), pesantren -atau sejenisnya semacam surau, dayah, dan lain-lain nama sesuai daerahnya- mendakwahkan Islam dengan ramah dan mudah berakomodasi dengan watak budaya nusantara. Sebagai lembaga pendidikan Islam tertua, pesantren mempunyai peran yang besar dalam proses Islamisasi (termasuk Islamisasi budaya) di Indonesia, dan bahkan di Asia Tenggara.

Kemampuan pesantren berakomodasi dengan watak budaya nusantara yang beraneka ragam secara mudah, dan tidak tertindas dengan kemajuan zaman, cukup menjadi bukti sejarah bahwa sejak awal pesantren telah melangkah dan berproses secara terbuka terhadap perbedaan dan keanekaragaman. Penelitian lapangan yang dilakukan oleh Lukens-Bull tahun 1997 di Arizona State University (ASU) Amerika Serikat, telah mendukung bukti ini, bahwa kaum pesantren telah berhasil mengukir identitas baru. Mereka menolak dua bentuk taklid sebagaimana yang dikemukakan oleh Kemal at-Taturk, dan bentuk penolakan Khumaini, terhadap segala sesuatu yang serba Barat dan modern karena komunitas pesantren sadar dan peka terhadap globalisasi dan Mc-Donalisasi, tetapi tetap aktif merespon globalisasi dengan jihad damai pendidikan pesantren (Mas'ud, 2005: 218).

Sejarah telah membuktikan bahwa keistimewaan yang behasil dicapai oleh pesantren karena didukung oleh adanya kurikulum pendidikan pesantren yang banyak memuat paham-paham pendidikan multikultural. Di antara contoh konkrit adalah kitab al-Milal wa an-Nihal, yang ditulis oleh al-Syahrastan (479-485 H). Kitab tersebut mengulas tentang firqah-firqah (golongangolongan) baik di dalam Islam maupun di luar Islam yang dipaparkan secara objektif tanpa adanya keperluan menghina atau pun memuji; kitab al-Figh 'al-Mazahib al-Arba'ah (kitab empat madzhab), ditulis oleh Al-Jazair, yang mengulas mengenai perbandingan pendapat ulama fiqih di lingkungan empat madzhab. Dari kedua kitab ini, cukup jelas sikap toleransi, penghargaan terhadap perbedaan, dan semangat multikultural yang ditanamkan (Hasyim, 2006: 66).

Pada masa perjuangan kemerdekaan hingga berdirinya Republik Indonesia ini, pesantren telah melahirkan tokoh nasional dan "Bapak Bangsa" misalnya, K.H. Hasyim Asy'ari dan putranya K.H.A. Wahid Hasyim, K.H. Ahmad Dahlan, K.H. Mas Mansur, Kahar Muzakkir, Ki Bagus Hadikusumo, H. Agus Salim, Sutan Syahrir, Hamka, dan lain-lain. Mereka adalah lulusan pesantren, yang tidak hanya menguasai bidang agama, juga karena komitmennya dalam mempertahankan nilai-nilai universal kemanusiaan yang tinggi, tetapi karena kepemimpinan dan semangat nasionalisme dan kebangsaannya yang tinggi. Di samping itu, mereka juga mengusung pendidikan Islam multikultural untuk keharmonisan hidup berbangsa yang mereka kembangan dengan baik untuk semua rakyat Indonesia.

\section{Perspektif Sosiologis}

Realitas sejarahnya yang panjang, pesantren telah menunjukkan perannya sebagai agen perubahan (agent of change) yang mampu merespon perkembangan modernisasi secara kritis serta mengarahkannya ke arah kehidupan yang lebih berwatak, kreatif, dan emansipatoris.

Hiroko Horikoshi, seorang antropolog Jepang dalam disertasinya yang berjudul "A Traditional Leadher in a Time if Change: The Kyai and Ulama' in West Java, (1976)" menegaskan bahwa kyai dan pesantren sangat berperan dalam proses perubahan sosial menuju ke arah kualitas kehidupan dan kerja yang lebih baik di lingkungan masyarakat sekitarnya.

Selain itu, Manfred Ziemek, berasal dari Jerman yang telah menulis disertasi berjudul "Pesantren Islamische Bildung in 
Sozialen Wandel" (telah diterjemahkan ke dalam Bahasa Indonesia menjadi Pesantren dan Perubahan Sosial, P3M, 1986), juga mengatakan bahwa kepemimpinan pesantren yang moralis, terbuka, humanis, dan emansipatoris telah berhasil mengantarkan pesantren sebagai agen perubahan yang kritis dan partisipatoris terhadap arus modernisasi yang tak terelakkan lagi dalam sejarah. Tesis Horikoshi dan Ziemek ini telah mengcounter tesis antropolog terkemuka Clifford Geertz yang cenderung kurang memberikan apresiasi terhadap peranan kyai sebagai agen perubahan sosial (Wahid, 2001: 46).

Dengan demikian, Islam multikultural adalah sebentuk perspektif teologis tentang penghargaan terhadap keragaman dan "sang lian" (the other). Suatu assessment teologis mengenai agama lain, kultur lain, dan etnik lain, dan penempatannya secara layak dalam wilayah tatanan publik etis.

Berdasarkan hal inilah perspektif teologis Abad XXI yang berkomunikasi melampaui bahasa dan tradisi partikular. Abdulaziz Sachedina, memberi istilah ini dengan ungkap "sensibilitas ekumene." Karena itu, dari perspektif teologi, pendidikan multicultural sesungguhnya menggambarkan perhatian dan kepedulian terhadap penduduk dunia, mempengaruhi kehidupan mereka melampaui batas-batas komunitas-komunitas keagamaan dan kultural. Tujuan luhur teologi multicultural adalah pembebasan dari belenggu kebodohan, kemiskinan, keterbelakangan, kezaliman, dan ketidakadilan sebagai akibat dari relasi kolonial atas-bawah, dominasi-subordinasi, superior-inferior, menindas-tertindas baik dalam hubungan antar agama, etnik dan budaya.

Bertolak dari konteks tersebut, maka memperbincangkan diskursus pendidikan Islam multikultural di Indonesia menemukan momentumnya. Selama ini Islam secara realitas seringkali ditafsirkan tunggal bukan jamak atau multikultural. Padahal, di Nusantara realitas Islam multikultural sangat kental, baik secara sosio-historis maupun glokal (global-lokal). Secara lokal, misalnya,
Islam di nusantara dibagi oleh Clifford Geertz dalam trikotomi: santri, abangan dan priyayi; atau dalam perspektif dikotomi Deliar Noer, yaitu Islam tradisional dan modern; dan masih banyak lagi pandangan lain seperti liberal, fundamental, moderat, radikal dan sebagainya. Secara sosio-historis, hadirnya Islam di Indonesia juga tidak bisa lepas dari konteks multikultural sebagaimana yang bisa dibaca dalam sejarah masuknya Islam ke Nusantara yang dibawa oleh Walisongo.

Berdasar pada ketiga diskursus di atas, pendidikan multikultural dalam Islam sebenarnya bukanlah hal baru. Hal ini paling tidak telah ditunjukkan oleh dunia pesantren dengan sistem dan pola pengajarannya yang sarat akan nilai-nilai multikultural. Kondisi demikian, tidak hanya dapat disaksikan melalui proses pengajaran dan pembelajarannya, tetapi juga materi atau kurikulum yang diajarkannya. Di pesantren -sepanjang pengamatan dan pengalaman penulis- senantiasa diajarkan nilai-nilai moralitas untuk saling menghormati dan menghargai antar ragam, corak dan kemajemukan yang ada di sesama umat manusia, baik perbedaan agama, adatistiadat, budaya, dan sebagainya. Inilah yang kemudian disebut dengan "tradisi pesantren", yang merupakan dialog dan pergulatan panjang antara doktrin Islam dan tradisi setempat.Di dalam pesantren, melalui ajaran moralitas dan tasawuf (akhlaq) yang disampaikan, telah berkembang ajaranajaran perlunya menjunjung tinggi sikapsikap toleransi (tasamuh), bersikap moderat (tawasu') dan senantiasa konsisten dan optimis (ta'adul dan istiqamah). Jadi, inilah nilai-nilai dasar pembentukan karakter yang mesti ditanamkan dalam diri siswa dan mahasiswa selanjutnya.

Dengan demikian, pendidikan Islam multikultural mencakup seluruh siswa (santri) dan mahasiswa tanpa membedakan kelompok-kelompoknya seperti gender, etnik, ras, budaya, daerah asal, dan strata sosial. 


\section{SIMPULAN}

Uraian yang telah dikemukakan di atas dapat diambil kesimpulan sebagai berikut:

Pendidikan Islam multikultural dapat merubah pola kehidupan masyarakat yang mendasar seperti integrasi sekolah dan perguruan tinggi. Peningkatan populasi imigran telah memberikan dampak yang besar pada lembaga-lembaga pendidikan. Di antara kegagalan siswa dari kelompok marjinal yang putus sekolah di sana, disebabkan oleh lemahnya pemahaman tentang "pengetahuan budaya" yang multi etnis, multi budaya, multi agama sebagai suatu keniscyaan untuk mencapai keberhasilan proses belajar mengajar di sekolah maupun proses perkulihan dan akademik bagi para mahasiswa di perguruan tinggi.

Ada beberapa langkah yang perlu ditempuh dalam pemahaman pengetahuan budaya kepada siswa dan mahasiswa tersebut, yaitu evolusi pendidikan multi budaya dalam fase-fase sebagai berikut. Pertama, ada upaya untuk mempersatukan kajian-kajian etnis pada setiap tingkat kurikulum 2013 sesuai dengan Kerangka Kualifikasi Nasional Indonesia.

Kedua, hal ini diikuti oleh pendidikan multi etnis, sebagai satu usaha untuk menerapkan persamaan pendidikan melalui reformasi keseluruhan sistem pendidikan. Ketiga, kelompok-kelompok marjinal yang lain seperti perempuan, orang cacat, kaum homo dan lesbi mulai menuntut perubahanperubahan mendasar dalam lembaga pendidikan.

Keempat, perkembangan teori, riset dan praktek mengenai pendidikan Islam multikultural ini perlu diperhatikan terutama pada hubungan antar ras, kelamin dan kelas (sosial) telah menghasilkan tujuan bersama bagi kebanyakan ahli teoritisi dan praktisi pendidikan Islam berwawasan multikultural.

\section{DAFTAR PUSTAKA}

Anwar, M. Syafii. 2006. "Menggali Kearifan Pesantren untuk Multikulturalisme", dalam Al-Wasathiyyah, Vol. 01, No. 01 Februari.
Fukuyama, Francis. 1999. The Great Disruption: Human Nature and the Reconstitution of Social Order. London: Profile Books. 2002. Trust: Kebajikan Sosial dan Penciptaan Kemakmuran (terj. Ruslani). Yogyakarta: Qirtas.

Gollnick, Donna M., Chinn, Philip C. 2002. Multicultural Education in a Pluralistic Society. New Jersey: Prentice-Hall.

Hamim, Thoha. 2001. "Islam dan Hubungan Antar Umat Beragama" dalam FORMA Surabaya: Majalah Mahasiswa Fak. Ushuluddin IAIN Sunan Ampel, 2001, Edisi XXVI: 2.

Hasyim, Syafiq. 2006. “Belajar Multikulturalisme dari Pesantren", dalam Jurnal Al-Wasathiyyah, Vol. 1, No. 1, Februari.

Hernandez, Hilda. 2001. Multicultural Education: A Teacher's Guide to Linking Context, Process, and Content. New Jersey: Prentice Hall.

Lawang, Robert M. Z. 2004. Kapital Sosial dalam Perspektif Sosiologik: Suatu Pengantar. Jakarta: Fisip UI Press.

Rahman, Budhy Munawwar. 2012. Pendidikan Karakter: Pendidikan Menghidupkan Kembali Nilai untuk Pesantren, Madrasah, dan Sekolah. Jakarta: Paramadina.

Nasution, S. 1996. Metode Penelitian Naturalistik-Kualitatif. Bandung: Tarsito.

Noorsalim, Mashudi, dkk. 2007. Hak Minoritas: Multikulturalisme dan Dilema Negara Bangsa. Jakarta: Interseksi Foundation.

Rachman, Budhy Munawar.2001. Islam Pluralis: Wacana Kesetaraan Kaum Beriman. Jakarta: Paramadina.

Rosyidi, Suherman .1996. Pengantar Teori Ekonomi: Pendekatan kepada Teori Ekonomi Mikro dan Makro. Jakarta: Raja Grafindo Persada.

Rozi, Syafuan. 2003. "Mendorong Laju Gerakan Multikulturalisme di Indonesia." Masyarakat Indonesia: Majalah 
Ilmu-ilmu Sosial Indonesia, Jilid XXIX, No. 1

Sabri, Mohammad.1999. Keberagamaan yang Saling Menyapa: Perspektif Filsafat Perennial: Yogyakarta: Bigraf.

Saerozi, M. 2004. Politik Pendidikan Agama dalam Era Pluralisme: Telaah Historis atas Kebijaksanaan Pendidikan Agama Konfesional di Indonesia. Yogyakarta: Tiara Wacana.

Scheerens, Jaap. 2000. Improving Shool Effectiveness. Paris: United Nations Educational, Scientific and Cultural Organization.

Suparlan, Parsudi. 2001. “Kesetaraan Warga dan Hak Budaya Komuniti dalam Masyarakat Majemuk Indonesia." Antropologi Indonesia, Tahun XXV, No. 66, September-Desember

2003. “Bhinneka Tunggal Ika: Keanekaragaman Sukubangsa atau Kebudayaan?" Antropologi Indonesia, Tahun XXVII, No. 72, SeptemberDesember
. 2003. “Kesukubangsaan dan Posisi Orang Cina dalam Masyarakat Majemuk Indonesia" Antropologi Indonesia, Tahun XXVII, No. 71, MeiAgustus

Tilaar, H.A.R. 2004. Multikulturalisme: Tantangan-tantangan Global Masa Depan dalam Transformasi Pendidikan Nasional. Jakarta: Grasindo

Tillman, Diane. 2002. Theoretical Background and Support for Living Valuess: An Educational Program. Deerfield Beach, FL: Healt Communications, Inc.

. 2002. Living Valuess Activities for Young Adults, terjemehan Risa Praptomo dan Ellen Sirait. Jakarta: Grasisndo.

Tilaar, H.A.R. 2004. Multikulturalisme Tantangan Global Masa Depan dalam Transformasi Pendidikan Nasional, Jakarta: PT. Gramedia Widia Sarana Indonesia.

Wahid, Marzuki. 2001. dalam Tashwirul Afkar, No. 11. 